\title{
Dissent on convergence: the role of public factors, international trade and path dependence
}

Citation for published version (APA):

Ziesemer, T. H. W. (1996). Dissent on convergence: the role of public factors, international trade and path dependence. MERIT, Maastricht Economic Research Institute on Innovation and Technology. MERIT Research Memoranda No. 004 https://doi.org/10.26481/umamer.1996004

Document status and date:

Published: 01/01/1996

DOI:

10.26481/umamer.1996004

Document Version:

Publisher's PDF, also known as Version of record

\section{Please check the document version of this publication:}

- A submitted manuscript is the version of the article upon submission and before peer-review. There can be important differences between the submitted version and the official published version of record.

People interested in the research are advised to contact the author for the final version of the publication, or visit the DOI to the publisher's website.

- The final author version and the galley proof are versions of the publication after peer review.

- The final published version features the final layout of the paper including the volume, issue and page numbers.

Link to publication

\footnotetext{
General rights rights.

- You may freely distribute the URL identifying the publication in the public portal. please follow below link for the End User Agreement:

www.umlib.nl/taverne-license

Take down policy

If you believe that this document breaches copyright please contact us at:

repository@maastrichtuniversity.nl

providing details and we will investigate your claim.
}

Copyright and moral rights for the publications made accessible in the public portal are retained by the authors and/or other copyright owners and it is a condition of accessing publications that users recognise and abide by the legal requirements associated with these

- Users may download and print one copy of any publication from the public portal for the purpose of private study or research.

- You may not further distribute the material or use it for any profit-making activity or commercial gain

If the publication is distributed under the terms of Article $25 \mathrm{fa}$ of the Dutch Copyright Act, indicated by the "Taverne" license above, 


\section{DISSENT ON CONVERGENCE: THE ROLE OF PUBLIC FACTORS, INTERNATIONAL TRADE AND PATH DEPENDENCE}

THOMAS ZIESEMER, Rijksuniversiteit Limburg|Maastricht, Department of Economics and MERIT, NL 6200 MD Maastricht.

\section{Introduction}

The distribution of world income across countries would approach an egalitarian one if countries with a lower level of the gross national product (GNP) had a higher growth rate of their GNP. Whether or not this convergence from low to high levels of GNP can be expected has been the subject of debate for a long time. Nowadays this debate takes place under the header of 'convergence'; in earlier days it was called the question of development and underdevelopment.

Optimists on this question tend to present evidence as in Figure 1. For this sample of countries we see that countries with a lower level of productivity in 1870 had higher growth rates from 1870 to 1979. The sceptics include more countries. This is shown in Figure 2. This figure no longer shows an obvious tendency towards convergence. On the contrary, it is remarkable here that among low income countries we see the broadest range of growth rates. Mankiw, Romer and Weil (1992, Table III) ${ }^{1}$ indeed show that the tests for unconditional convergence yield a tendency towards convergence for the OECD sample but not for their two larger samples.

However, this does not mean that the convergence view is completely wrong. Mankiw (1995), based on Barro and Sala-i-Martin (1991) and MRW (1992), defends the convergence idea. Once one corrects for different savings rates and rates of population growth, they argue, the convergence view is correct.

This argument is presented more precisely using the neoclassical growth model. The neoclassical growth model considers convergence from the point of view of capital accumulation. The capital-labour ratio $\mathrm{k}=\mathrm{K} / \mathrm{AL}$, with $\mathrm{K}$ the stock of capital, A the stock of technical knowledge and $L$ the exogenous labour hours, often called population, grows at rate ${ }^{2}$

$$
\hat{k}=\hat{K}-\hat{A}-\hat{L}
$$

With a linear homogeneous production function for capital and efficient labour, $\mathrm{Y}=\mathrm{F}(\mathrm{K}, \mathrm{AL})$, a constant savings ratio, $\mathrm{s}$, and investment equal to savings, the rate of growth of the capital stock can be written as

\footnotetext{
${ }^{1}$ Henceforth this reference is abbreviated as MRW.

${ }^{2} \mathrm{~A}$ hat indicates a growth rate of the variable in question.
} 
For Figure 1 see Baumol, W.J. (1986), Productivity Growth, Convergence and Welfare: What the Long-Run Data Show, American Economic Review, 1072-85.

For Figure 2 see Grossman, G.M. and E. Helpman (1991), Innovation and Growth in the Global Economy, Cambridge Mass., MIT Press, p. 3 .

$$
\hat{K}=s F(K, A L) / K
$$

Insertion of the rate of growth of the capital stock into the 
equation for the growth rate of the capital-labour ratio yields

$$
\hat{k}=s F(K, A L) / K-\hat{A}-\hat{L}
$$

This is drawn in Figure 3. The vertical difference between the two curves is the growth rate of the capital-labour ratio. The model economy moves to $\mathrm{k}^{*}$. The lower the initial value of the capital-labour ratio, the higher the growth rate and the more time it takes until the steady state is reached, up to a certain percentage. ${ }^{3}$ Using alpha as the production elasticity of capital, the growth rate of per capita GNP for this closed economy model can be written as

$$
\hat{Y}-\hat{L}=\hat{A}-\alpha \hat{k}
$$

In the steady state the growth rate of the capital-labour ratio is zero and the economy would grow at the growth rate of $A$. Outside the steady state the second term is positive and therefore the growth rate is higher the greater the distance between $\mathrm{k}$ and $\mathrm{k}^{*}$, $\mathrm{i} . e$. , if the country is poorer it grows more quickly. If countries had identical savings ratios and identical rates of population growth they would grow to the same $\mathrm{k}^{*}$, provided that they have the same elasticities of production and the same rate of technical progress. The latter is an assumption made by MRW, who interpret technology as an international public good.

Mankiw (1995) defends this model as realistic because MRW (1992) obtained an adjusted $R^{2}=0.59$ for the steady state version of the model. This may come as a surprise for the reader who is familiar with the MRW paper. There the result for the OECD sample is a rather poor adjusted $R^{2}=0.06$ and an elasticity of production for capital of 0.6 , whereas the authors expect $1 / 3$ as a realistic result based on income statistics. Mankiw argues that human capital should be included here instead of in labour income. The MRW model then is augmented by endogenous human capital and the convergence process, which results in an adjusted $\mathrm{R}^{2}=0.66$ for the OECD sample, 0.46 for the non-oil sample consisting of 98 countries and 0.44 for an intermediate sample omitting small countries. Whereas the result for the OECD countries is what one would expect on the basis of Figure 1, we see that as soon as developing countries are in the sample the result is much worse.

The purpose of this paper is to present some arguments that can explain the effects of differences between developed and developing countries. Sharing Mankiw's view that the Solow (1956)

${ }^{3}$ Note that in this model with an exogenous savings rate the steady state is never reached but only an asymptotic result. 


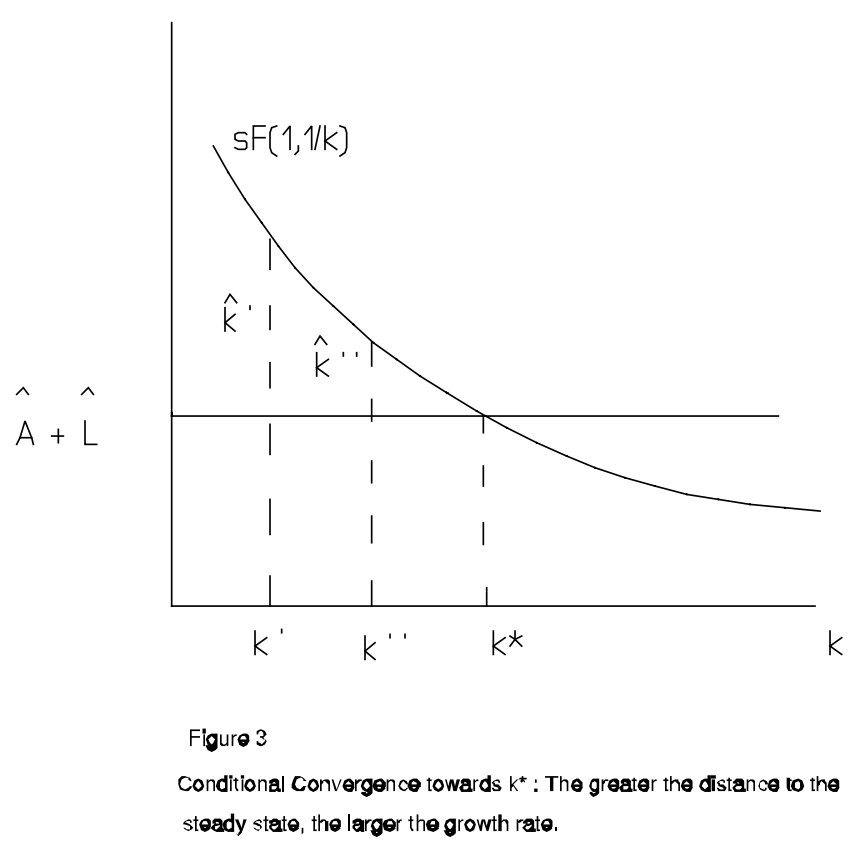

model is the natural starting point ${ }^{4}$, some suggestions to improve it are straightforward. ${ }^{5}$

First, as the central driving force, exogenous technical progress is interpreted as a public good by MRW that is available without cost and therefore identical across countries. Technical progress and public goods should be endogenous because then they are costly and it becomes clear what the implications of these costs are. Growth rate effects of investment in public factors are discussed in section 2 and level effects in section 3 . Second, with so much emphasis on capital accumulation in the Solow model, one should be aware of the fact that at least nonOECD countries are importers of capital goods. These imports have to be paid for by exports either immediately, or later if debt is incurred. Unless one imposes the perfectly unrealistic small country assumption, export demand is limited, and the long-run growth rate will be determined not only by technical progress but also by income and price elasticities of export demand functions.

${ }^{4}$ Mankiw's motivation is that the model is realistic. My motivation is that the central institution of world economic policy, the IMF, seems to believe, too, that the solow model gives us a good idea of what would happen to the long term development if developing country governments behave efficiently. In Ziesemer (1987) I have collected and developed models which contain arguments suggesting that this neoclassical view is far too optimistic. Its ignorance of many problems can lead to lower growth rates than the solow model would predict.

${ }^{5}$ For critical remarks concerning technology and microfoundations see the comment of Paul Romer on Mankiw (1995). 
As there is little reason to believe that these are identical across countries, identical steady-state growth rates cannot be expected to prevail. This and other trade and capital movements arguments will be discussed in section 4.

Finally, Figure 2 shows that quite a few countries have negative growth rates of per capita income. Decreasing returns to scale as well as path dependence models can explain this, whereas the closed economy Solow model cannot. We present some of these arguments in section 5 .

\section{Growth rate effects of endogenous public factors}

Technical progress will be endogenized along the lines suggested by T.W. Schultz (1964). It depends on human capital which in turn depends on the public factors basic education and basic scientific research. The more the government invests in these public factors the more human capital will be produced by households and the more technical progress will be generated by firms. ${ }^{6}$ Ignoring physical capital for a moment, output is assumed to be produced by a neoclassical production function $\mathrm{Y}=\mathrm{F}\left(\mathrm{H}, \mathrm{AL}_{1}\right)$ where $\mathrm{H}$ is human capital, and the same notation as above is used for the other variables. Technical progress is generated by the neoclassical production function

$$
\dot{A}=G\left(H / L_{1}, A\right)=g(h) A \text { with } h \equiv H / A L_{1}
$$

Division by $L_{1}$ indicates that human capital is less productive in making technical progress the more workers there are to whom the knowledge has to be transferred. The more knowledge the firm has produced the more productive it is in doing so in the future. This is indicated by the second argument. Human capital is supplied by families $i=1, \ldots, N$ using heterogeneous neoclassical production functions

$$
H^{i}=H\left(e^{i} A L^{i}{ }_{2}, B\right)
$$

Households use labour weighted by firm knowledge, individually different ability parameters $e^{i}$ and public factors B. Ability parameters make these households different from each other, an assumption that prevents the occurrence of an egalitarian income distribution. The change in the stock of public factors is paid by a flat rate income tax, $t$ :

$$
\dot{B}=t Y
$$

In equilibrium, demand for human capital $\mathrm{H}$ in the production and technical progress functions must be equal to the sum of individual supplies $\mathrm{H}^{\mathrm{i}}$. Labour supply must be equal to the sum of labour demand of the firm, $L_{1}$, and the sum of labour used in human capital production. It can be shown that in this model the rate of technical progress will be higher the higher the flat

${ }^{6}$ For a more detailed explanation and analysis of the following see Ziesemer (1995a). 
rate income tax.

This model ignores the distortion of taxes on capital income because it neglects capital income altogether. In shell (1967) this distortion has a negative impact on the growth rate, thus weakening the expenditure effect of having more public factors. Empirically, Easterly and Rebelo (1993) find that this distortive effect is insignificant, and Koester and Kormendi (1989) find that income tax distortions have level effects but no growth rate effects. The expenditure effect therefore is empirically dominating and found by Otani and Villanueva (1990) to be quantitatively as important as the rate of saving. They find that for low and middle income countries, a 1 percentage point increase in the ratio of government expenditure on human capital to GNP would on average contribute a 0.5 percentage point increase in the long-term per capita annual growth rate of output.

Why then do countries' governments not spend the same amount on education? There are mainly two reasons for this. First, taxation is a form of savings, and the inclination towards savings may depend on the level of income. So far we would simply be back to the conditional convergence argument: Since taxes being parts of savings, their inclusion is a refinement of making convergence conditional on savings by disaggregating savings into their components. To this we will return below.

Second, different abilities $e^{i}$ in the human capital production function generate a different marginal contribution of public factors in households' income formation. This is shown in Figure 4, where the vertical intercept of the tangential lines is equal to the marginal product of public factors in human capital formation. Production functions drawn for higher abilities have a higher vertical intercept. People with higher abilities are more interested in a high level of public factors and therefore have a higher willingness to pay. Unless there is perfect information on the side of the government concerning households' marginal benefits from public factors, which would allow for Lindahl taxes, there will be a distributional conflict: People with higher abilities want higher flat rate taxes, people with lower abilities want lower tax rates. The inclusion of capital income would of course have an impact here: people with higher capital income will c.p. desire lower levels of taxes. If the political conflict is dominated by large capital income owners or low ability people, the result will be a low rate of taxation, a low level of public factors, scarce human capital and a low rate of technical progress. From this argument alone there is little reason to believe that countries will converge to the same rate of technical progress in the long run, unless one imposes the belief that the political decisions also converge in the long run. However, in economics we have no such argument available until now.

Although the results of Otani and Villanueva (1990) do not contradict the view expressed in the model above, we cannot distinguish whether their results hold for the steady state or 


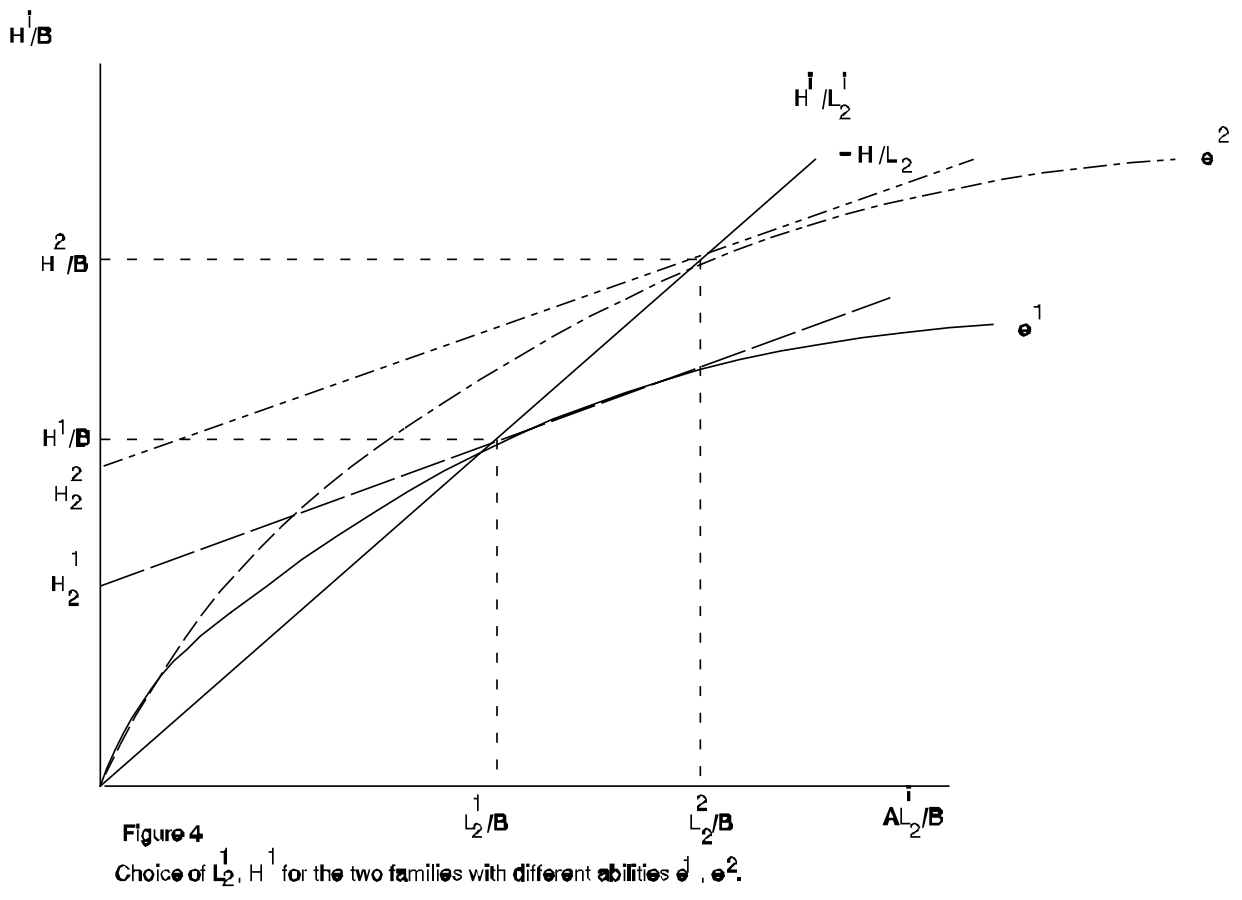

only for transitional periods. ${ }^{7}$ In the latter case the tax variable may have only a level effect. This is all the more the case if there are no improvements at all in total factor productivity of developing countries. This is a common view in development economics that has recently been supported by Young (1994). Young's computations yield total factor productivity increases for the period 1970-85 for 65 of 118 countries. Almost half of the countries, therefore, may not have total factor productivity improvements. ${ }^{8}$ However, even if the output production does not have a total factor productivity term that grows, a public factor in the production of one of the inputs may generate a similar effect due to the non-rivalry of using the public factor. These so- called level efects will be considered in the next section. In future research this will be extended to

${ }^{7}$ Indeed the coefficient in question compared across three groups of countries is lower the richer the group of countries considered (see Otani and Villanueva 1990, Table 3).

${ }^{8}$ These estimates may be biased downwards because in the ranking of countries, we have switzerland in the 66th place with no gain in total factor productivity. This result is hard to believe. It raises the question of whether or not the calculations have taken the degree of capacity utilization into account or whether exchange rate problems haved biased these calculations. A low degree of capacity utilization in the period of time covering the two oil crises and the world recession after 1980 may be responsible for this low estimate. See also Morisson 1989 for the impact of the degree of capacity utilization on estimates of total factor productivity. 
sector specific public factors, which may lead to an intermediate position between laissez-faire and targeting.

\section{Level effects of endogenous public factors}

To analyze level effects, we drop A-terms from the previous equations and introduce physical capital. The major argument to be made is that private and public capital have to be well balanced to allow for an optimal level of GNP per capita. The output production function now becomes

$$
Y=K^{\alpha} H^{\beta} L_{1}^{1-\alpha-\beta}
$$

The human capital production function remains the same as (2.2) above with $A=1$. The equation for the change in the stock of public factors remains (2.3). An equation for the accumulation of physical capital with symbols as above has to be added

$$
\dot{K}=s(1-t) Y
$$

In this model ${ }^{9}$ labour is allocated in proportion to the elasticities of production

$$
L_{1} / L_{2}=(1-\alpha-\beta) /(\varphi \beta)
$$

All individual production functions in this model have constant returns to scale. Inserting the results of the model into the production function, it can be shown that the non-rivalry of public factors in the human capital production function lead to increasing returns in the aggregate production function

$$
Y=K^{\alpha}\left\{L_{2} e^{i}\left[B /\left(e^{i} L_{2}{ }^{i}\right)\right]^{(1-\varphi)}\right\} \beta L_{1}{ }^{(1-\alpha-\beta)}
$$

This function is homogenous of degree $1+\beta(1-\varphi)$ in $K, B, L_{1}$ and $\mathrm{L}_{2}$. Public factors' elasticity of production is equal to the degree of increasing returns to scale in the aggregate production function because this elasticity reflects the productivity of the non-rivalry property of public capital.

The long-run growth rate of this model is

$$
\begin{aligned}
& \hat{Y}=\hat{K}=\hat{B}=g \equiv \frac{(1-\alpha) n}{1-\alpha-\beta(1-\varphi)}>n \\
& \hat{H}=n \frac{1-\alpha+(1-\varphi)(1-\alpha-\beta)}{1-\alpha-\beta(1-\varphi)}>g>n
\end{aligned}
$$

The growth rate of human capital is larger than that of output,

\footnotetext{
${ }^{9}$ See Ziesemer (1990) for more detailed motivations, derivation and discussion of results.
} 


$$
\hat{W}=\hat{Y}-\hat{L}_{1}=\hat{Y}-\hat{L}=\frac{\beta(1-\varphi) n}{1-\alpha-\beta(1-\varphi)}
$$

physical and public capital. ${ }^{10}$ The difference between the two is proportional to the elasticity of production of public capital in human capital formation. The growth rate of real wages, labour productivity and per capita income is equal to the number of additional people using the public factors weighted by the elasticity of production of public factors in final output.

A golden rule maximizing steady-state per capita consumption can be shown to require

$$
t=\beta(1-\varphi) \text { and } s=\alpha /[1-\beta(1-\varphi)]=\alpha /(1-t)
$$

As in the steady state, we have $g K=s(1-t)$ and $g B=t y$ the composition of capital in the steady state and under a golden rule is

$$
B / K=t / s(1-t)=\beta(1-\varphi) / \alpha
$$

However, this optimal composition of capital is unlikely to be achieved. The reason is as follows. In this model individuals are allowed to differ with respect to their abilities $e^{i}$, capital endowment $K^{i}$ and labour endowments. It can be shown that for an individual with average abilities defined as a choice $\mathrm{L}_{2}{ }^{i} / \mathrm{L}=1 / \mathrm{N}$ and average income $\mathrm{Y}^{\mathrm{i}}=\mathrm{Y} / \mathrm{N}$, a Lindahl tax is as high as the golden rule tax. A person that has higher income or lower abilities prefers a lower tax. If the distribution of total income per unit of labour spent in education is such that the median voter has a lower income per unit of labour spent in education than the average person, he will prefer a higher flat rate of taxation than the golden rule, leading to a lower growth path. Tax rates that are very much higher or lower than the golden rule and the median voter's ideal tax rate will lead to even greater deviations from the golden rule path. This is summarized in Figure 5.

As Mankiw (1995) has analyzed the impact of the savings ratio on the level of per capita income, we concentrate on the impact of the composition of the two capital stocks, $\mathrm{B} / \mathrm{K}$, and the two parts of total savings: the tax rate, $t$, and the private rate of savings, s. In order to do so we assume that the aggregate savings rate is at its optimal level

$$
t+s(1-t)=\beta(1-\varphi)+\alpha
$$

Solving this for $s$ we get

${ }^{10}$ It should be clear that the argument of public factors increasing human capital are less relevant if there is educated unemployment because wage policy prevents human capital prices from falling. However, the more economies are deregulated under the guidance of the IMF policies, the more relevant are the arguments of this paper which have been formulated for undistorted economies. 


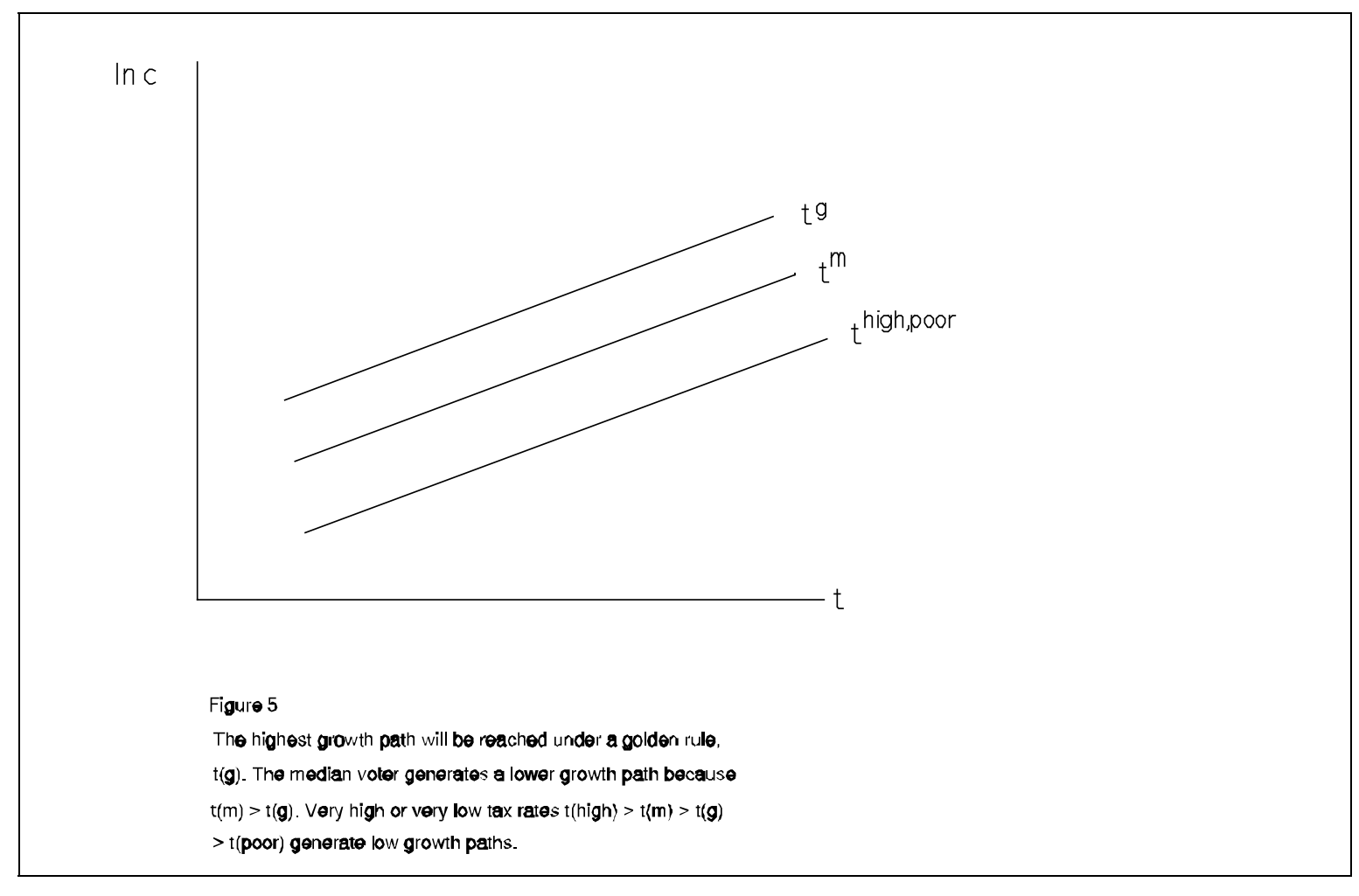

$$
s=[\alpha+\beta(1-\varphi)-t] /(1-t)
$$

If the denominator is required to be positive, the tax rate has an upper bound of alpha plus the rate of increasing returns. Under the assumption of optimal aggregate savings, this implies that any change in the tax rate will be accompanied by an opposite change in the rate of private savings as given below by

$$
d s / d t=-(1-s) /(1-t)
$$

As the labour allocation is independent of the rates of savings and taxation, and for the purpose of analyzing the impact of a change in the rate of taxation given optimal total savings, the aggregate production function (3.4) can be rewritten as

$$
Y=K^{\alpha} B^{(1-\varphi) \beta} \Gamma
$$

Inserting of the steady state results $g K=s(1-t) Y$ and $g B=t Y$ for $\mathrm{K}$ and $\mathrm{B}$, respectively, into (3.10), after dividing both equations by $g$, replacing the savings ratio by (3.9) and solving for $Y$, yields

$$
Y=\left\{\frac{[\alpha+\beta(1-\varphi)-t]}{g}\right\} \frac{\alpha}{\frac{\alpha}{1-\alpha-\beta(1-\phi)]}}\left(\frac{t}{g}\right)^{\frac{\beta(1-\varphi)}{1-\alpha-\beta(1-\varphi)}} \Gamma
$$

This is the aggregate production function for the steady state as a function of the tax rate, but only under the precondition that the aggregate savings rate is optimal as in (3.9), where the latter assumption ensures that only the structural effect of the tax rate is taken into account. Increasing the tax rate increases 
the value of $B$ in the second term but decreases the value of $K$ in the first term. The elasticity of output with respect to the tax rate can be computed as

$$
\varepsilon_{Y t}=\frac{\left[-\frac{\alpha t}{\alpha+\beta(1-\varphi)-t}+\beta(1-\varphi)\right]}{[1-\alpha-\beta(1-\varphi)]}
$$

This elasticity equals

i)

$$
\frac{(1-\varphi) \beta}{1-\alpha-\beta(1-\varphi)} \text { for } t=0
$$

ii) zero for the golden rule tax $t=\beta(1-\varphi)$ and

iii) minus infinity for the tax value $t=\alpha+\beta(1-\varphi)$ for which $s=0$.

In words, for taxes lower than the golden rule, the elasticity with respect to output is positive because it improves the composition of capital, changing it into the direction of a golden rule. At the golden rule it is of course zero. At tax rates higher than the golden rule, output decreases. Investment in public factors, ty, has its maximum value at an elasticity of $(-1)$, where $t=(1-\alpha)[\alpha+\beta(1-\varphi)]$. If the elasticity is smaller than (-1) there is a Laffer effect: decreasing the tax rate increases output more than proportionately such that tax revenues increase.

These exercises show that not only the level of savings matters, but also the size of the government, measured by the share of public investment. This adds another condition besides the savings ratios and rates of population growth taken into account by MRW. An estimate by Koester and Kormendi (1989) shows that $\partial(\mathrm{Y} / \mathrm{L}) / \partial t=2.48$, meaning that an increase by 1 percentage point $(d t=1 \%)$ increases the GDP per capita on average by $\$ 248$, which is $8.6 \%$ of the median per capita income of their sample of $\$ 2880$ in 1975 U.S. dollars. By interpreting the numbers using the calculations of the model presented above, this means that the actual tax rates are on average below that of the golden rule value in a cross section of countries.

As wages income, $\mathrm{wL}_{1}$, is a constant share of output, it will also be higher under a higher rate of taxation. The same results holds for non-capital income, $\mathrm{wL}_{1}+\mathrm{qH}=(1-\alpha) \mathrm{Y}$. Higher investment in public factors therefore can, at least partly, answer the question posed in the discussion of Mankiw (1995) why a household migrating from Mexico to the US earns more in the latter. As long as the percentage increase of per capita income is higher then the percentage point change of the tax rate this also holds for the post-tax income. 


\section{International trade and factor movements}

Using a closed economy solow model ignores that capital goods are imported by developing countries and therefore have to be paid by exports either immediately or later if debt is incurred. Therefore we show the impact of income and price elasticities of export demand on the long-run growth rate. As these elasticities can hardly be expected to be equal across countries, this provides another argument against the assumption of identical steady-state growth rates across countries.

The importance of capital goods imports has been pervasive throughout Prebisch's (1950, 1961) and Singer's (1950, 1958, 1991) papers and today is a common argument in the whole of the literature on dependency theory.

A first step in examining the consequences of the introduction of imported capital goods into the neoclassical growth model has been made by Bardhan and S. Lewis (1970). The model presented below ${ }^{11}$ contains several modifications of theirs in a simplified way. Both do not try to explain the importation of capital goods but rather examine its consequences for the terms of trade, capital accumulation and real wage growth.

As in the previous model a Cobb-Douglas function is used

$$
Y=e^{b t} K^{\beta} L^{1-\beta} \quad \text { or } \quad \hat{Y}=b+\beta \hat{K}+(1-\beta) \hat{L}
$$

with $b$ as the rate of technical progress and all the other symbols the same as in the previous model. Labour is assumed to grow at an exogenously given rate $\mathrm{n}$ as in the previous model

$$
L(t)=L(0) e^{n t} \text { or } \hat{L}=n
$$

An important problem for developing countries seems to be that the international allocation is such that they are importers of capital goods. This problem is repeatedly mentioned in Prebisch's papers (1950, pp. 12,17; 1961, pp.5,11,12). We assume that only capital goods are imported. By assumption, capital goods invested in each period, denoted by $\dot{K}$, must be imported, and there are no other imports such that $M=\dot{K}$, where $M$ denotes imports. Since imports are assumed to consist of capital goods only, the trade balance equilibrium requires that they are paid for by exports. So investment is limited by exports $\mathrm{X}$, valued in terms of imported capital goods (see Prebisch, 1950, p.2)

$$
\dot{K} / K=p X / K \text { or } \hat{\hat{K}}=\hat{p}+\hat{X}-\hat{K}
$$

where $\mathrm{p}$ is the terms of trade, i.e., the price of domestic goods

${ }^{11}$ The model is a slightly modified version of Ziesemer (1987, Chap.7.5), which has been applied to the discussion of the Prebisch-Singer Thesis in Ziesemer (1995b) and to the debt crises in Ziesemer (1996). 
in terms of the imported capital goods. Investment has to be financed by domestic savings measured in units of imported capital goods. Again a constant rate of savings, s, from national output is assumed

$$
\operatorname{spY} / K=\dot{K} / K \text { or } \hat{\hat{K}}=\hat{p}+\hat{Y}-\hat{K}
$$

Investment, being limited by exports, cannot grow faster than exports. Exports are assumed to depend on customer countries' income $z$ and the terms of trade $p$. The reader is reminded that Prebisch assumed a low income elasticity of export demand (Prebisch, 1959, pp.251/2) and a price elasticity greater than minus infinity, (1961, p.5) and even greater than minus one; in short, he assumed low income and price elasticities of export demand (1959, p.256). Faini et. al (1992, Hentschel (1992) and Stern, Francis and Schumacher (1976) found indeed that the values of price elasticities of exports are in the neighbourhood of minus one. As we will see later, low elasticities of export demand may be the reason for slow investment growth and other important variables if capital goods are imported. To ease computation the export function is assumed to be log-linear

$$
X=e^{\omega t} p^{\eta} \text { or } X=Z^{\rho} p^{\eta} \text { and } X=\omega+\eta \hat{p}=\rho \hat{z}+\eta \hat{p}
$$

rho is the income elasticity and eta the price elasticity of export demand. The first formulation is the one used by Bardhan and Lewis (1970), and the second is used in the models of Thirlwall (1983). Both formulations are equivalent if $\omega=\rho \hat{z}$. This equivalence allows us to relate the Bardhan- Lewis model to the Prebisch-Singer problem of low elasticities. Given wage and interest rates, the usual marginal productivity conditions for competitive markets from profit maximization hold

$$
\begin{aligned}
& r=p e^{b t} \beta K^{\beta-1} L^{1-\beta} \text { or } \hat{r}=\hat{p}+b+(\beta-1)(\hat{K}-\hat{L}) \\
& w=p e^{b t} K^{\beta}(1-\beta) L^{-\beta} \text { or } \hat{w}=\hat{p}+b+\beta(\hat{K}-\hat{L})
\end{aligned}
$$

where $w$ is the wage rate measured in units of foreign goods and $\mathrm{w} / \mathrm{p}$ is the wage rate measured in units of domestic goods. Inserting the growth rate versions of the production function and the export function into the savings and the export constraint for investment, (4.3) and (4.4), yields

$$
\begin{aligned}
& \hat{\hat{K}}=\hat{p}+\rho \hat{Z}+\eta \hat{p}-\hat{K} \\
& \hat{\hat{K}}=\hat{p}+b+\beta \hat{K}+(1-\beta) \hat{L}-\hat{K}
\end{aligned}
$$

The wage rate--used as a rough indicator of welfare here--will grow at the same rate at which the marginal productivity of labour grows. The latter is determined by the rate of technical 
progress and the growth rate of the capital-labour ratio, henceforth defined as $\mathrm{k} \equiv \mathrm{K} / \mathrm{L}$

$$
\hat{w}-\hat{p}=b+\beta \hat{k}
$$

The rate of technical progress being given exogenously, the critical point is whether the growth rate of the capital-labour ratio is slowed down by low export elasticities, which in turn limit imports of capital goods. The solution of the model in terms of growth rates for the long-run equilibrium growth path interpreted below, can be obtained as follows. Solving (4.4') for $\hat{p}$ and inserting it into (4.3') yields, after some manipulation

$$
\hat{\hat{K}}=\frac{\rho \hat{z}-(1+\eta) b-(1+\eta)(1-\beta) n}{-\eta}+\frac{-\beta+\eta(1-\beta)}{-\eta} \hat{K}
$$

In the $(\hat{\hat{K}}, \hat{K})$ plane this is a linear differential equation with a negative slope. A price-elastic export demand function is a sufficient condition for obtaining positive intercepts (drawn in

Figure 1). Setting $\hat{\hat{K}}=0$ and going back to the other equations, the solution for the terms of trade, the capital-labour ratio and real wages can be computed as follows

$$
\begin{aligned}
& \hat{p}=[(\rho \hat{z}-n)(1-\beta)-b] /[-\eta(1-\beta)+\beta] \\
& \hat{k}=[\rho \hat{z}-n-(1+\eta) b] /[-\eta(1-\beta)+\beta] \\
& \hat{w}-\hat{p}=[(\rho \hat{z}-n) \beta-\eta b] /[-\eta(1-\beta)+\beta]
\end{aligned}
$$

As the denominator is positive for all three equations, the interpretation will first focus on the numerator, and thereafter (4.8) and (4.10) will be drawn in Figures 6 and 7. This demonstrates the dependence of the terms of trade and the real wage on the income elasticity of exports, $\rho$, for alternative values of the price elasticity of exports $\eta$. The numerator in (4.8)-(4.10) is the sum of two terms. The first term captures the "engine of growth" part in the spirit of Prebisch, Singer and Myrdal, but also Lewis and others. That is, customer countries' income growth multiplied by the income elasticity drives the growth rates of the terms of trade, capital-labour ratios and the wage rate. The second term captures the "handmaiden" part of the story, made possible here through the explicit introduction of technical progress in the Bardhan-Lewis model. This is more in the spirit of Kravis (1970) who argued that exports are merely driven by the price decreasing effects of technical progress. Therefore the causality goes from growth to exports and not the other way around, as emphasized by the 'engine of growth' proponents. This view has recently been supported by Evans 


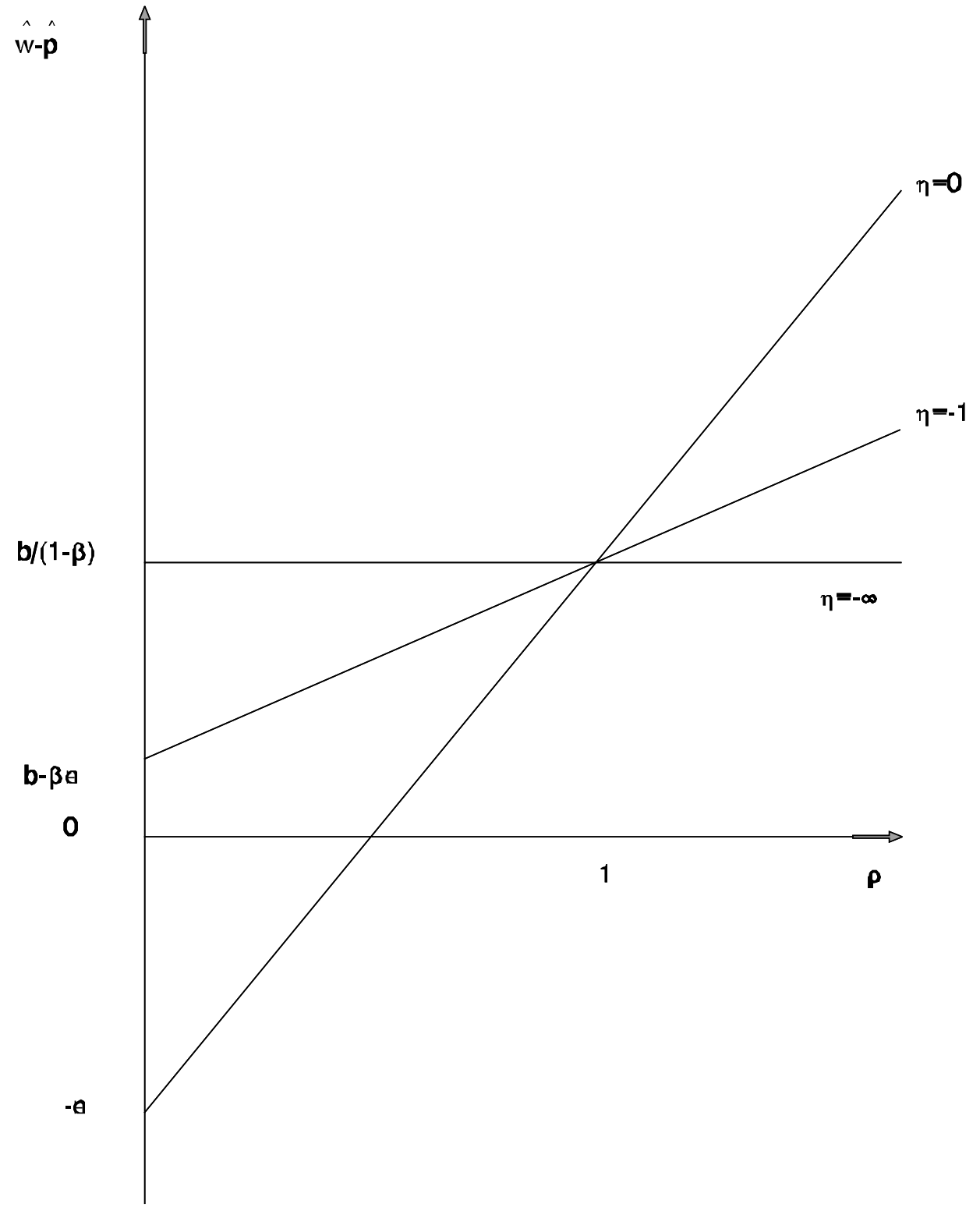

Figure 6

The growth rate of real wages increases with the income elasticity of exports. This is drawn for $\hat{Z}=n+b /(1-\beta)$ and alternative values of price elasticity $\eta$. 


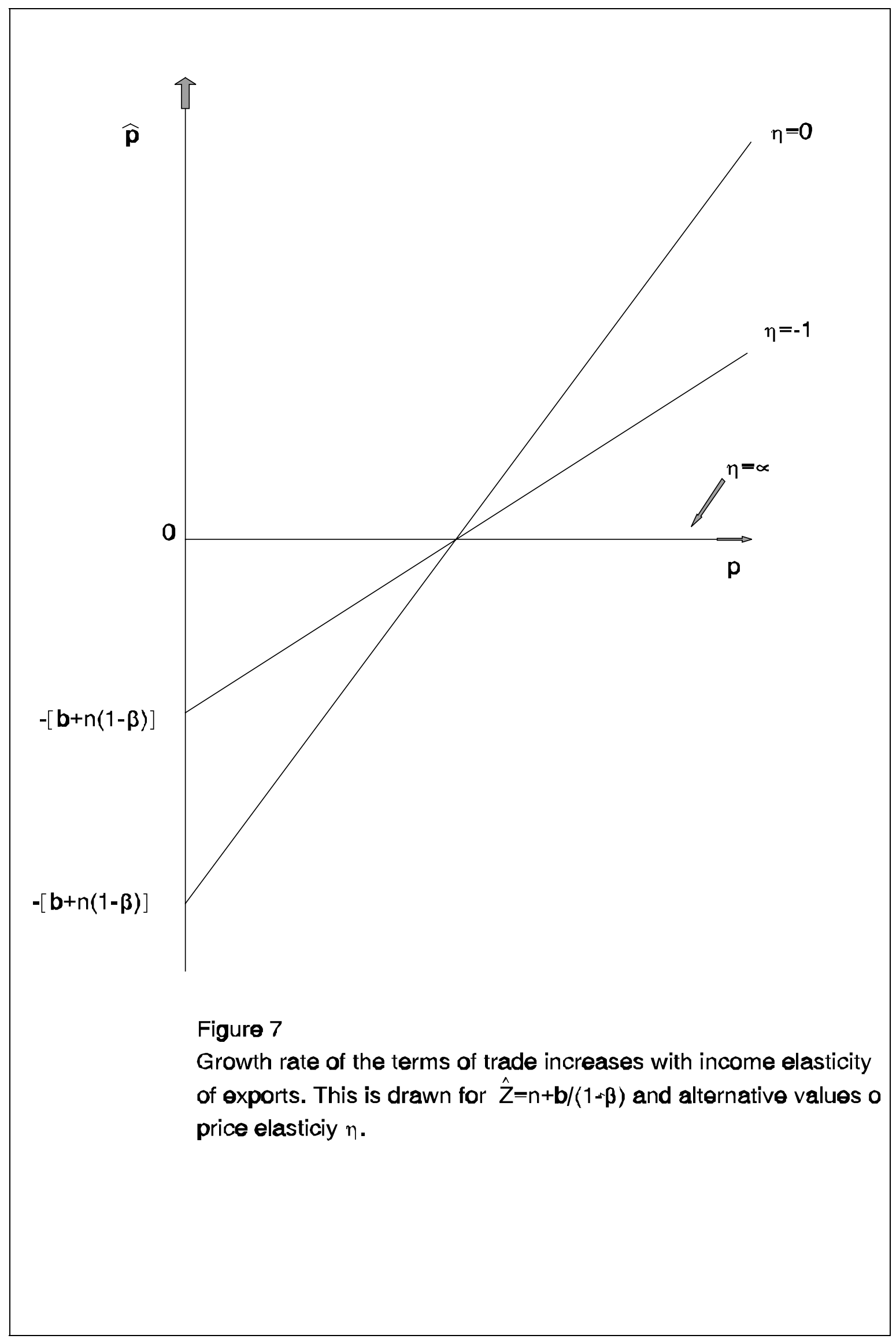


(1987). Evans assumes that capital goods could be produced within the South. However, the assumption that they are not is crucial to the way in which this paper perceives the P-S thesis. This model contains both features which will be discussed in greater detail now.

The benefits from technical progress may be described as follows: The immediate effect of technical progress is to reduce production costs; it reduces the terms of trade in (4.8). This was recognized by Prebisch (1950, p.5, fn.4). The question now is, whether this effect will lead to increasing or decreasing exports and investment. If exports are price-elastic they will be increased and will therefore enhance the rate of growth of the capital-labour ratio in (4.9). If exports are price-inelastic, technical progress, by decreasing the terms of trade, has a negative effect on the rate of growth of the capital-labour ratio in (4.9). Now technical progress has a direct and an indirect influence on the real wage growth rate, the indirect effect resulting via the capital-labour ratio. It can be seen that the direct effect outweighs the indirect effect as in (4.10). Nevertheless, the less price elastic the export demand function is, the smaller the contribution of technical progress to real wage growth. ${ }^{12}$ In the limit, if price elasticities were zero, there would be no influence of technical progress on the growth rate of the real wage rate. To summarize, technical progress has a negative impact on the terms of trade and a non-negative influence on real wages. As there is little reason to believe that countries will have identical price elasticities, even if they had identical rates of technical progress, it is implausible to expect identical long-run growth rates across countries.

A second argument why one should not expect identical longrun growth rates is that the income elasticity of export demand

and customer countries' income growth, $\rho \hat{Z}$, cannot be expected to be identical across countries. A higher income elasticity yields a higher growth of export demand for each given growth rate of customer countries' income. It also leads to higher growth rates of capital imports in (4.9), leading to higher real wage growth in (4.10) and therefore higher growth rates of the terms of trade in (4.8). A critical problem is whether the increase of exports, induced by the rate of growth of customer

countries' income, $\rho \hat{z}$, is higher than the rate of population growth because the difference determines the rate of growth of

${ }^{12}$ Note that this argument refers only to the term in the numerator, i.e., the role of the price elasticity with respect to technical progress. The total effect of varying the price elasticity on real wages can be seen from Figure 6. For a given income elasticity a higher price elasticity decreases the real wage growth rate if the income elasticity is larger than one. It increases it if it is smaller than one, because a higher price elasticity implies a lower terms of trade gain (to the right of the intersection point in Figure 7) or loss (to the left of the intersection point) for any given value of other variables. 
the capital-labour ratio in (4.9). If the difference between the product just mentioned and the rate of population growth is negative because of a low income elasticity of export demand, $\rho$, this will have a negative impact on the terms of trade, the capital-labour ratio and real wage growth. So, the terms of trade, the capital-labour ratio and the real wage, all depend on the income elasticity of export demand in the same way (see Prebisch, 1959, p.258).

A comparison with the results of the solow growth model is an essential point of this paper and is therefore carried out next. In the closed neoclassical growth model with a production function as in (4.1), the real wage, the capital-labour ratio and per capita income grow at the rate $b /(1-\beta)$. The impact of income and price elasticities can be summarized by rearranging (4.10) such that it has two components: the steady-state growth rate of the neoclassical model and a term containing income and price elasticities. The result is

$$
\hat{w}-\hat{p}=\frac{b}{(1-\beta)}+\frac{(\rho \hat{z}-n) \beta-\beta b /(1-\beta)}{-\eta(1-\beta)+\beta}
$$

Obviously, a higher income elasticity of export demand has a positive impact on the growth rate, and a price elasticity that is higher in absolute terms has a negative impact. There are two special cases in which the neoclassical result can be derived from (4.11)

1 For $\eta$ equal to minus infinity we have $\hat{w}-\hat{p}=b /(1-\beta)$ for all values of $\rho \hat{z}$. This is the neoclassical small country case.

2. If we assume that the world as a whole grows like a closed Solow economy at the rate $\hat{Z}=n+b /(1-\beta)$ then we find

$$
\hat{W}-\hat{p}=b /(1-\beta) \text { and } \hat{p}=0 \text {, both if } \rho=1
$$

In this case the engine of growth $\hat{Z}-n$ is as fast as the handmaiden, $\mathrm{b} /(1-\beta)$.

$$
\hat{w}-\hat{p} \text { is drawn in Figure } 6 \text { as a function of } \rho \text { under the }
$$

assumption of $\hat{Z}=n+b /(1-\beta)$ for alternative values of $\eta^{13}$. Whereas the small country case--drawn as a horizontal line in Figure 6--reflects the predominant traditional neoclassical view that exports do not limit growth (see Donges and Riedel, 1977), the second case reminds us of a paper by Seers (1962), who argued that growth differences are due to differences in the income

${ }^{13}$ For the derivation (4.10') and (4.11) have been used; vertical intercepts and slopes are derived in Appendix I of Ziesemer 1995b. 
elasticities of export demand. Figure 6 shows that an income elasticity lower (higher) than one yields lower (higher) growth rates than in the solow model if capital goods are imported and the price elasticity is not minus infinity. The impact of the income elasticity on the growth rate is still higher if exports are less price elastic, because then price movements have a less smoothing impact on growth rates.

As the model is not only driven by technical progress but by exports as well, a similar relation between the terms of trade and the income elasticity of export demand is drawn in Figure 7 ${ }^{14}$. Whenever the income elasticity of export demand is smaller than one, the terms of trade fall and the real wage grows slower than in the Solow economy, thus showing the close relationship between real wages and terms of trade development. Both are governed by the income elasticity of export demand, whose impact is increased (decreased) through lower (higher) price elasticity of export demand.

Capital goods importation and low elasticities of export demand were the main issues presented by Prebisch (1950, 1959) and Singer $(1950,479)$. Nothing in the model depends on primary products, which were used as an example in the 1950's, although primary products are still of great importance (see Barros and Amazonas 1993, p. 99-102, and Hoffmann and Zivkovic 1992). The strong growth of (semi-)manufactured industry goods is also a broadly accepted fact in recent years (see Donges and Riedel 1977 and Sapsford, Sarkar and Singer 1992). What matters are elasticities of export demand--regardless of the nature of the products--and their impact on real wages and per capita income as a measure of poverty or wealth. Income elasticities of export demand seem to favour differential growth rates because different countries specialize in different products which have different income elasticities of demand. Finally, the model allows for decreasing, constant and increasing growth in the terms of trade and therefore may provide a good basis for empirical research. In this sense we hope that the model may be viewed as a step towards an improved basis of formal theorizing for empirical research. However, it cannot be expected that empirical research will find identical steady state growth rates as assumed in the conditional convergence view of MRW.

A first impression can be obtained from recent estimates of long-run trends in terms of trade development. The order of magnitude under discussion is a fall in the terms of trade between zero and $0.8 \% .{ }^{15}$ The second term in $(4.11)$ has the same sign as the terms of trade result (4.8). This means that even if the total factor productivity increases at the same percentage rate in all countries of the world as in the first term of (4.11), the second term is negative for many countries which import capital goods but have falling terms of trade. Note that

\footnotetext{
${ }^{14}$ For a derivation (4.11) has been used and vertical intercepts and slopes are derived in Appendix II of Ziesemer $1995 b$.

${ }^{15}$ See Cuddington and Urzua (1989), Ardeni and Wright (1992), Bleany and Greenaway (1993) and Barros and Amazonas (1993).
} 
there is no compelling reason for the specialization assumed to vanish under falling terms of trade. In the vein of Ricardian theory, the specialization is robust if the relative total factor productivities are falling even faster than the terms of trade. In the vein of Heckscher-Ohlin theory, one could think of capital goods as being human capital intensive, a factor that remains relatively abundant in the developed countries.

To summarize, low income and price elasticities lead to low growth rates and may even make the growth rates of the terms of trade, the capital-labour ratio and the real wage rate negative in (4.8)-(4.10). It is unreasonable to expect identical price and income elasticities of export demand and therefore no convergence towards steady states with identical growth rates can be expected.

A second reason for not having identical growth rates has been presented by Grossman and Helpman (1991). In a dynamic Heckscher-Ohlin framework, they argue, that growth rates are produced by an $R \& D$ sector with human capital intensive technology. Therefore, a country that is human capital abundant can be expected to have a higher growth rate than a less human capital abundant country. If international trade equalizes factor prices, capital mobility would not change the result. The more human capital abundant country is and will remain richer. If factor prices are not equalized by trade alone, interest rates may be too high to allow poor countries to do any R\&D at all. Again, identical long-run growth rates cannot be expected to prevail.

The endogenization of R\&D by Grossman and Helpman (1991) undermines the traditional Heckscher-Ohlin result on convergence of Fischer and Frenkel (1974), who argued that two growing Heckscher-Ohlin economies, allowing for capital movements, would immediately equalize their GDPs and in the long run also their GNPs. This is because the poorer country, having the same savings ratio as the richer country by assumption, would in the long run own as much capital as the initially richer country. In the long run both countries are absolutely identical, trade is balanced and capital movements vanish. There are no gains from trade in the long run; they all accrue in the transition to but not at the steady state.

Given the fairly well developed state of modelling exogenous growth with international capital movements ${ }^{16}$, it is somewhat surprising that MRW used a closed economy model. Obviously, the reason is that under perfect capital movements used in most of the models, profit maximizing firms, equating their marginal product of capital to the world market interest rate, fix the capital-efficient labour ratio. As a consequence, the capitallabour ratio, output per capita and real wages grow at the rate of technical progress immediately. There is no transition because the unretarded inflow of capital is tantamount to a jump to a new steady state. But having a transition process is essential in MRW to get good empirical results.

Barro, Mankiw and Sala-i-Martin (1995) are aware of this

${ }^{16}$ See Ziesemer (1995c, Chap.3), for a survey of these models developed in the sixties and seventies. 
deficiency of the MRW paper. They show that a credit constrained economy, defined as one in which only part of the capital stock can serve as collateral, can have almost the same properties as the closed economy. This gives, of course, more plausibility to the empirical results.

However, it should be noted that the formal equivalence is made for two totally different interpretations. What was physical and human capital in the closed economy model, and the data used in the empirical work, for the open economy, is redefined to be collateralized and non-collateralized capital. One wonders with which data this can be fulfilled and whether or not the results would be as good as before. If two formally equivalent models have different interpretations, and therefore need different data sets to test them, the answer is far from obvious. However, the point of departure in this paper was the fact that the adjusted $\mathrm{R}_{2}$ was worse for a set of countries that include developing countries. This result is seemingly also unaffected by the transition to an open economy model.

In earlier models capital market imperfection had already been taken into account. Hamada (1969) made spreads on the world market interest rate dependent on the debt per capita. Countries with higher debt pay higher spreads. As countries with higher debt have lower wealth owned, this implies a higher marginal product of capital for a poorer country as in the closed economy model of Solow and MRW. Hamada's model, therefore, would have been the most straightforward tool for the MRW work. However, Mankiw's motivation was to defend the solow model as empirically relevant. Due to its closed economy nature, and the fact that the USA itself has been built with UK capital as many developing countries have financed their investment with US capital ${ }^{17}$, it could have been made clear without sophisticated econometrics that the value of the Solow model is didactical in nature. It is a starting point for more sophisticated theorizing rather than a realistic description of the mechanics of economic development.

Similarly, Ziesemer (1996) integrates debt and spreads into the above Prebisch-Singer growth model, making them dependent on variables that have turned out to be robust in the empirical literature on country risk, creditworthiness and debt servicing capacity. This also yields a transition process of the model to the steady state. However, the steady-state growth rate is the same as in the model presented above, and, therefore steady-state growth rates will supposedly differ across countries. Therefore, no convergence can be expected except for that of a country to its own steady state. Empirical work on convergence under conditions of international capital movements still has to be done. The models of Hamada (1969), Barro, Mankiw and Sala-iMartin (1995) are the most straightforward tools to do this. However, for a group of countries that import capital goods, separate estimates should be run with these models and with that of Ziesemer (1996). If the latter yields better results than the former, this would be evidence against convergence, because here countries have different steady state growth rates.

${ }^{17}$ See Fishlow 1985 on the history of international debt and development. 


\section{Explaining negative growth rates: Trade again, population growth and path dependence}

Figure 2 shows sixteen countries with negative annual average growth rates of per capita income for the period 196085. ${ }^{18}$ The Solow model predicts positive growth rates for poor countries unless extremely high values of population growth and extremely low values of the rate of savings are assumed for a given capital-labour ratio (see Figure 3). For poor countries other models may be more adequate to explain these negative rates, because it is difficult to imagine how a country can get to a point $\mathrm{k}>\mathrm{k}^{*}$.

However, if the production function is linear homogenous in respect to capital, efficient labour and land, and land is nonaugmentable and normalized to unity, then we have decreasing returns to capital and labour

$$
\begin{gathered}
Y=K^{\alpha}(A L)^{\beta}, \alpha+\beta<1 \\
\hat{Y}=\alpha \hat{K}+\beta(\hat{A}+\hat{L})
\end{gathered}
$$

This is a reasonable assumption for agrarian economies which are among the poorest. ${ }^{19}$ If investment equals savings with a constant savings ratio, we get

$$
\hat{K}=s Y / K \text { or } \hat{\hat{K}}=\hat{Y}-\hat{K}
$$

Inserting the growth rate version of the production function into the growth rate version of the equality of investment and savings, we get

$$
\hat{\hat{K}}=\alpha \hat{K}+\beta(\hat{A}+\hat{L})-\hat{K}
$$

This is drawn in Figure 8 . The model is driven to a constant rate of capital accumulation

$$
\hat{K}=\frac{\beta(\hat{A}+\hat{L})}{1-\alpha}
$$

Output per capita becomes

This equation has the familiar interpretation from Ricardo's theory. Unless technical progress is large enough to outweigh the decreasing returns to scale entered because of population growth,

${ }^{18}$ Supposedly this number would be even higher if the whole of the 1980s had been included, because they are well known as the lost decade now.

${ }^{19}$ This is a simplified model of Jorgenson 1961. See Ziesemer 1987, chaps.4 and 5 for a more detailed discussion. The model could also be written down with international capital movements. For the sake of brevity this is not done here. 


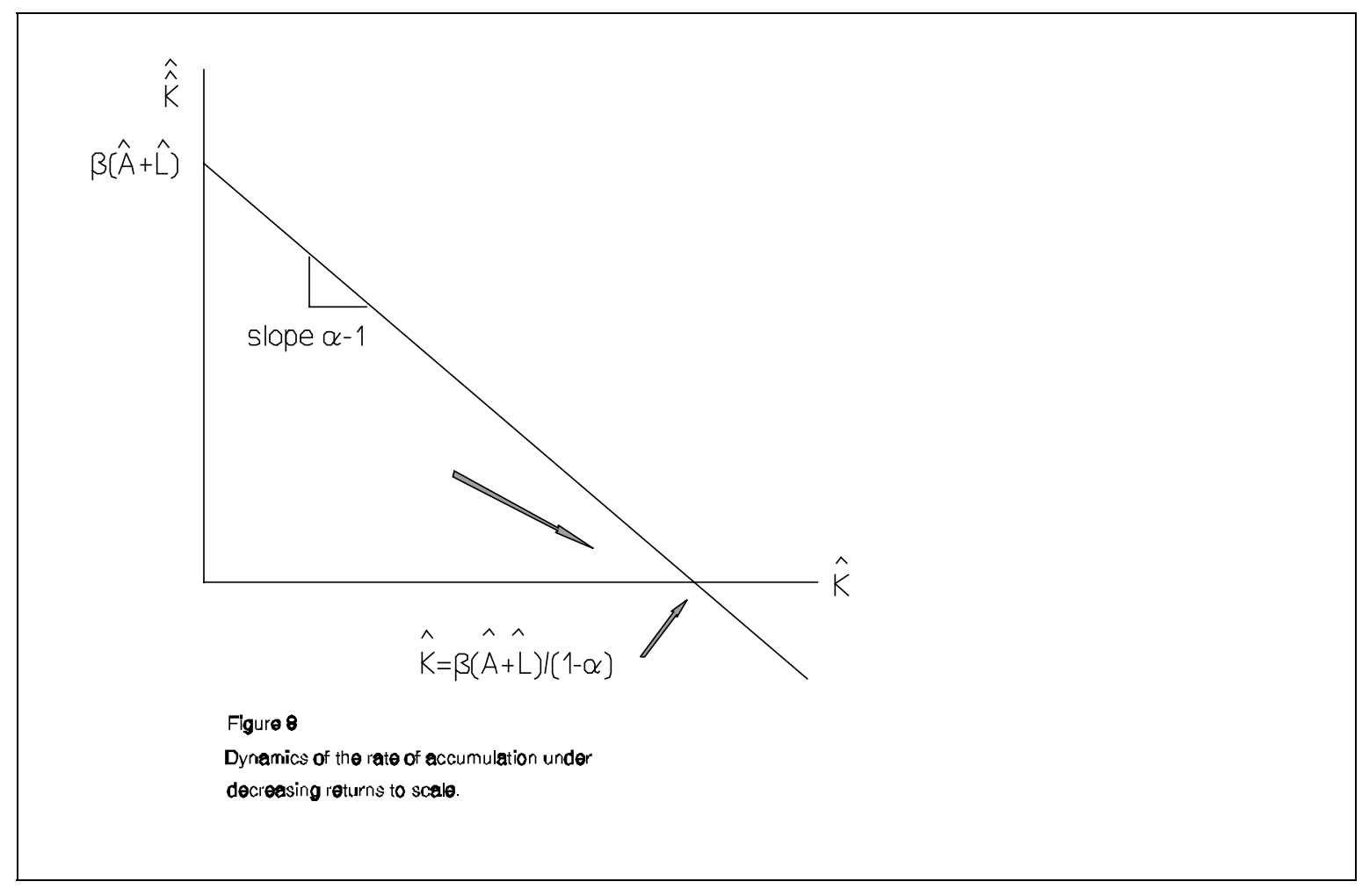

$$
\begin{gathered}
\hat{Y}-\hat{L}=\alpha \hat{K}+\beta \hat{A}+(\beta-1) \hat{L} \\
=\alpha \frac{\beta(\hat{A}+\hat{L})}{1-\alpha}+\beta \hat{A}+(\beta-1) \hat{L} \\
=\frac{\beta \hat{A}-(1-\alpha-\beta) \hat{L}}{1-\alpha}
\end{gathered}
$$

per capita income will fall.

A second explanation can be given using the Prebisch-Singer growth model of the previous section. It is obvious from Figure 6 that a low income elasticity of export demand or customer countries' incomes can lead to negative growth rates.

Third, path dependent models with thresholds to development are obvious candidates to explain negative growth rates. Models with endogenous population growth and population trap are legendary and need not be repeated here.

Fourth, path dependence in (endogenous) growth models can be found very often (see Schneider and Ziesemer 1995). They all have three steady states, two of which are stable and one of them which is unstable. Unless the central variable of the model has an initial value that is higher than the threshold value of the unstable steady state, the economy will grow towards the low level equilibrium trap and have negative growth rates in the transition. The only model that has been constructed to explain the growth of developing countries, the group for which the convergence results of MRW are less satisfactory, however, is the one by Becker, Murphy and Tamura (1990).

The essence of the model can be briefly described as follows. The human capital of the child generation, $H_{t+1}$, is dependent on the human capital of the parent generation, $\mathrm{H}_{\mathrm{t}}$, that is used h hours, to educate children. The simplest way to write 
the education production function is $H_{t+1}=h H_{t}$. Parents, determining the number of hours spent on education, $h$, take into account that they could use their time alternatively for raising more children with less education or offer their time on the labour market. The more human capital a child has, the higher her future utility. The utility of the future generation is taken into account by altruistic parents, who give the future generation a higher weight in their utility function the more children there are. However, the weight given to each child is decreasing per child. As a consequence of these assumptions, parents who have little human capital are less productive in education and prefer to have more children which will be less educated, thus generating a higher weight to the future generation, but a lower weight for each child. This latter lower weight for each child implies also lower education. The time spent on education, therefore, also depends on the given human capital: $h\left(H_{t}\right)$, with $h^{\prime}>0$. The production function now becomes $\mathrm{H}_{\mathrm{t}+1}=\mathrm{h}\left(\mathrm{H}_{\mathrm{t}}\right) \mathrm{H}_{\mathrm{t}}$. In $\mathrm{H}_{\mathrm{t}+1}-\mathrm{H}_{\mathrm{t}}$ space, this can be drawn as shown in Figure 9. The slope is positive throughout: $\mathrm{dH}_{\mathrm{t}+1} / \mathrm{dH}_{\mathrm{t}}=\mathrm{h}^{\prime} \mathrm{H}_{\mathrm{t}}+\mathrm{H}>$ 0 . The second derivative must change from positive to negative because $\mathrm{d}^{2} \mathrm{H}_{\mathrm{t}+1} /\left(\mathrm{dH}_{\mathrm{t}}\right)=\mathrm{h}^{\prime}$ ' $\mathrm{H}_{\mathrm{t}}+2 \mathrm{~h}$ ' is positive for small $\mathrm{H}_{\mathrm{t}}$ and negative for large $H_{t}$ if $h^{\prime}{ }^{\prime}<0$. If parameters of the model are such that the S-curve intersects the 45-degree line, the economy will move as indicated by the arrows. The poor become poorer, the rich become richer. If some countries start above and others below the threshold value, the result is called divergence, .

\section{Summary and conclusion}

Starting from the fact that the MRW results yields a lower adjusted $\mathrm{R}^{2}$ for samples larger than that of the OECD, we have concluded that there must be arguments specific to developing countries which can explain this difference in explanatory power. The following arguments have been presented.

We have shown that endogenizing public factors attributes a special role to tax resistance and the structure of public expenditure. A lower share of public expenditure on education may lead to a lower steady state growth rate in the model of section 2 and a lower share of public investment in GNP may lead to a lower level of per capita income in the model of section 3 .

Taking into account that capital goods are imported, the model of section 4 shows the long-run growth rate to include income and price elasticities of export demand, which must be expected to differ across countries.

Endogenization of R\&D in dynamic Heckscher-Ohlin models of Grossman and Helpman (1991) must be expected to yield different long-run growth rates as well.

The empirical investigation of models with international capital movements is a totally open issue.

Finally, explanation of negative growth rates is much more plausible in models of i) decreasing returns, ii) the PrebischSinger model of section 4, iii) path dependent models of endogenous population growth and iv) path dependent models of endogenous growth.

The advantage and merit of the MRW model is that it is the 


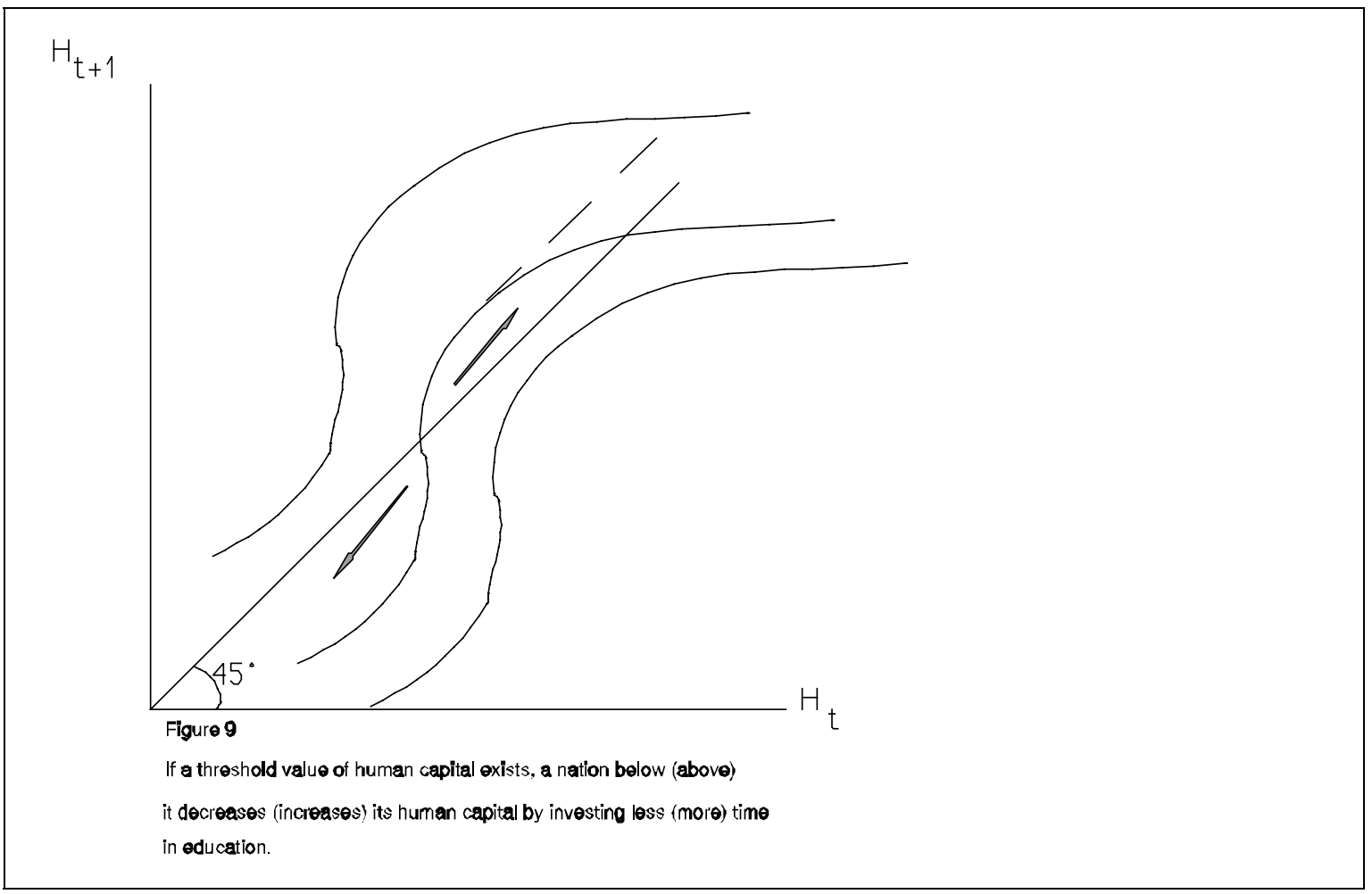

only model in the recent wave of growth theory that has undergone rigorous estimation and testing until now. Although the results are fairly good according to general standards, MRWs sophistication of using three samples has also revealed that the purely macro-neoclassical approach may be improved by using arguments from public, international and development economics presented in this paper.

\section{References}

Ardeni, P.G. and B. Wright (1992), The Prebisch-Singer Hypothesis: A Reappraisal Independent of Stationarity Hypothesis, Economic Journal, Vol. 102, No.413, July.

Bardhan, P.K. and S. Lewis (1970), Models of Growth with Imported Inputs, Economica, November, p.373.

Barro, R.J., N.G. Mankiw and X. Sala-i-Martin (1995), Capital Mobility in Neoclassical Models of Growth, American Economic Review, March 1995, Vol.85, No.1, 103-115.

Barro, R.J. and X. Sala-i-Martin (1991), Convergence Across States and Regions, Brookings Papers on Economic Activity, 10758 .

Barros, A.R. and A. Amazonas (1993), On the Deterioration of the Net Barter Terms of Trade for Primary Commodities, Unctad Review, No. 4, 99-116.

Becker, G.S., K.M. Murphy and R. Tamura (1990), Human Capital, 
Fertility and Economic Growth, Journal of Political Economy, $98(5)$, Part 2, October, 12-37.

Bleany, M.F. and D. Greenaway (1993), Long-run Trends in the Relative Price of Primary Commodities and in the Terms of Trade of Developing Countries, Oxford Economic papers 45, 349-363.

Cuddington, J.T. and C.M. Urzua (1989), Trends and Cycles in the Net Barter Terms of Trade: A New Approach, Economic Journal, Vol. $99,426-442$.

Donges, J.B. and J. Riedel (1977), The Expansion of Manufactured Exports in Developing Countries. An Empirical Assessment of Supply and Demand Issue. Weltwirtschaftliches Archiv, Vol. 113, pp. 58-87.

Easterly, W. and S. Rebelo (1993), Marginal Income Tax Rates and Economic Growth in Developing Countries, European Economic Review, 37, 408-417.

Evans, D. (1987), The Long-run Determinants of North-South Terms of Trade and some Recent Empirical Evidence, World Development, Vol. 15, 657-671.

Faini, R., F. Clavijo and A. Senhadji-Semlali (1992), The Fallacy of Composition Argument: Does Demand matter for LDC manufactured exports? European Economic Review, vol.36, No.4, May, 865-882.

Fischer, S. and J.A. Frenkel (1974), Economic Growth and Stages of the Balance of Payments, In: G. Horwich and P.A. Samuelson (eds.), Trade, Stability and Macroeconomics: Essays in Honor of L.A. Metzler, Academic Press, New York, 503-521.

Fishlow, A. (1985), Lessons from the Past: Capital Markets during the 19th century and the interwar period, International Organization 39, 3, Summer, 383-439.

Grossman, G.M. and E. Helpman (1991), Innovation and Growth in the Global Economy, Cambridge, Mass., MIT Press.

Hamada, K. (1969), Optimal Capital Accumulation by an Economy Facing and International Capital Market, Journal of Political Economy, 684-697.

Hentschel, J. (1992), Imports and Growth in Highly Indebted Countries, An Empirical Study, Springer Verlag, Berlin Heidelberg New York.

Hoffmann, U. and D. Zivkovic (1992), Demand Growth for Industrial Raw Materials and Its Determinants: An Analysis for the Period 1965-1988, UNCTAD Discussion Papers No. 50, November.

Jorgenson, D.W. (1961), The Development of Dual Economy, Economic Journal, Vol. 71, June 1961, pp.309-334.

Koester, R.B. and R. Kormendi (1989), Taxation, Aggregate 
Activity and Economic Growth: Cross Country Evidence on some Supply-Side Hypotheses, Economic Inquiry, 27, 367-386.

Kravis, I.B. (1970), Trade as a Handmaiden of Growth, Economic Journal, December, 850-872.

Mankiw, N.G. (1995), The Growth of Nations, Brookings Papers on Economic Activity, 1, 275-326.

D. Romer and D. Weil (1992), A Contribution to the Empirics of Growth, Quarterly Journal of Economics 107 (2): 40737 .

Morisson, C. (1989), Unravelling the Productivity Slowdown in the U.S., Canada and japan: The Effects of Subequilibrium, Scale Economies and Markups, NBER WP 2993, June. Review of Economics and Statistics 1993.

Otani, I. and D. Villanueva (1990), Long-Term Growth in Developing Countries and Its Determinants: An Empirical Analysis, World Development, Vol. 18, No.6, 769-783.

Prebisch, R. (1950), The Economic Development of Latin America and its Principal Problems, Economic Bulletin for Latin America, Vol. VII, No. 1, February 1962 (reprinted), p.1-22.

(1959): Commercial Policy in the Underdeveloped Countries, The American Economic Review, Vol. XL IX/2, May

(1961): Economic Development or Monetary Stability, The False Dilemma, Economic Bulletin for Latin America, Vol. VI, No.1, March 1961, p.1-25.

Sapsford, D., P. Sarkar and H.W. Singer (1929), The PrebischSinger Terms of Trade Controversy Revisited, Journal of International Development 4, no.3.

Schneider, J. and T. Ziesemer (1995), What's New and What's Old in New Growth Theory: Endogenous Technology, Microfoundations and Growth Rate Predictions. A Critical Overview. Zeitschrift für Wirtschafts- und Sozialwissenschaften, Vol.115, No.3, 429-472.

Schultz, T.W. (1964), Transforming Traditional Agriculture, Yale University Press.

Seers, D. (1962), A Model of Comparative Rates of Growth in the World Economy, The Economic Journal, No. 285, March 1962, Vol. LXXII.

Shell, K. (1967), A Model of Inventive Activity and Capital Accumulation, in: Essays on the Theory of Optimal Growth, edited by Karl Shell, 67-85. Cambridge, MA: MIT Press.

Singer, H.W. (1950), The Distribution of Gains between Investing and Borrowing Countries, The American Economic Review, Vol.40, No. 2, p.473-486. 
(1958), Comment on Charles P. Kindleberger, The Terms of Trade and Economic development, Review of Economics and Statistics 40, 72-90.

(1991), Terms of Trade: New Wine and New Bottles? Development Policy Review, Vol.9, No.4, December.

Solow, R.M. (1956): A Contribution to the Theory of Economic Growth, Quarterly Journal of Economics, LXX, 1, February 1956, p. 65-94.

Stern, R.M., J. Francis and B. Schumacher (1976), Price Elasticities in International Trade, Macmillan, London.

Thirlwall, A.P. (1983), Foreign Trade Elasticities in Centre-Periphery Models of Growth and Development, Banca Nazionale Del Lavaro. Quarterly Review, Sept. 1983, pp.249-261.

Young, A. (1994), Lessons from the East Asian NICs: A Contrarian View, European Economic Review, May.

Ziesemer, T. (1987), Economic Theory of Underdevelopment, transfer Verlag, Regensburg.

(1990, Public Factors and Democracy in Poverty Analysis, Oxford Economic Papers, 42, 268-280.

(1995a), Endogenous Growth with Public Factors and Heterogeneous Human Capital Producers, Finanzarchiv, Neue Folge, Band 52, Heft 1, 1-20.

1995b, Economic Development and Endogenous Terms-ofTrade Determination: Review and Reinterpretation of the PrebischSinger Thesis, UNCTAD Review, 17-34.

(1995c), Ursachen von Verschuldungskrisen: Theorie, Empirie and Politik, Habilitationsschrift, September (mimeo).

(1996), A Prebisch-Singer Growth Model and the Debt Crises, Paper prepared for "DEVELOPMENT ECONOMICS and POLICY", A Conference to Celebrate the 85th Birthday of Professor Sir Hans Singer, Innsbruck, Austria 1st-5th May 1996.

JEL-Class.: 011,041 
